\title{
Indirect evaluation of digestive tract function on male lambs and ram based on feed digestibility and eating behavior
}

\author{
A. Prima, E. Rianto, E. Purbowati and A. Purnomoadi* \\ Faculty of Animal and Agricultural Sciences, Diponegoro University \\ Tembalang Campus Semarang 50275, Central Java - Indonesia \\ *Corresponding E-mail: agung194@yahoo.com
}

Received September 13, 2017; Accepted February 02, 2018

\begin{abstract}
ABSTRAK
Penelitian bertujuan untuk mengkaji perkembangan dan fungsi organ pencernaan domba muda dalam mencerna pakan berdasarkan evaluasi nilai kecernaan dan tingkah laku makan. Materi yang digunakan sebanyak 11 ekor domba muda umur 3-4 bulan, bobot badan (BB) 14,78 $\pm 1,99 \mathrm{~kg}$ (CV 3,98\%) dan 11 ekor domba dewasa umur 10-12 bulan, BB 22,18 $\pm 1,81 \mathrm{~kg}$ (CV 3,29\%). Penelitian ini menggunakan rancangan acak lengkap pola tersarang $2 \times 2$, dimana terdapat dua umur yang dibandingkan (muda vs dewasa) dan di dalam umur tersarang pakan, yakni rumput gajah 100\% (G100) vs pakan pelet tersusun dari 50\% rumput gajah 50\% konsentrat (G50C50). Pakan diberikan 3,5\% dari BB. Parameter yang diamati adalah kecernaan nutrien, waktu makan dan ruminasi. Hasil penelitian menunjukkan konsumsi (rata-rata 3,33\% DM) dan kecernaan (rata-rata 49\%) pada domba muda dan dewasa tidak berbeda nyata. Waktu makan (192,56 menit/hari) dan ruminasi (364 menit/hari) pada domba muda dan domba dewasa tidak berbeda nyata. Kecernaan pakan G50C50 lebih tinggi $(\mathrm{P}<0,05)$ dari pada G100 (50,49\% vs 47,53\%). Waktu makan (47 vs 338 menit/hari) dan ruminasi (305 vs 423 menit/hari) pada pakan G50C50 lebih sedikit $(\mathrm{P}<0,05)$ dari pada G100. Disimpulkan bahwa saluran pencernaan domba muda sudah berkembang dan berfungsi sama dengan domba dewasa.
\end{abstract}

Kata kunci: fungsi saluran pencernaan, domba muda, kecernaan, tingkah laku makan

\begin{abstract}
This study was aimed to examine the development and function of digestive organs of lamb in digesting feed based on feed digestibility value and eating behaviour. The materials used were 11 lambs aged 3-4 months, body weight (BW) $14.78 \pm 1.99 \mathrm{~kg}$ (CV 3.98\%), and 11 rams aged 10-12 months, BW $22.18 \pm 1.81 \mathrm{~kg}$ (CV 3.29\%). The study used a completely randomized design of $2 \times 2$ in nested patterns. There were two ages compared (lambs vs ram) and every age was nested the diet i.e. 100\% Napier grass (G100) vs mixed pellet 50\% grass and 50\% concentrate (G50C50). The diet was given at $3.5 \%$ of BW. Parameters observed were dry matter intake (DMI) and digestibility, eating and ruminating time. The results showed that were no significant differences between lambs and rams in DMI (averaged 3.33\% BW), digestibility (averaged 49.00\%), eating (192.56 min/d), and ruminating (364 min/d). Animals given diet G50C50 had higher $(\mathrm{P}<0.05)$ DMI (666 vs $565 \mathrm{~g} / \mathrm{d})$ ), digestibility $(50.49 \%$ vs $47.53 \%)$, and less $(\mathrm{P}<0.05)$ eating ( $47 \mathrm{vs} 338 \mathrm{~min} / \mathrm{d})$ and ruminating (305 vs $423 \mathrm{~min} / \mathrm{d})$, as compared with those fed diet G100. It is concluded that the digestive tracts of lambs had developed and function to the stage similar to ram.
\end{abstract}

Keywords: digestive tract function, lambs, digestibility, eating behaviour 


\section{INTRODUCTION}

Early fattening of lambs is one of the efforts to increase efficiency of the time, lands and feed resources, reduce total waste disposal and accelerate supply of high quality meat (Purnomoadi et al., 2016). In practical, the fattening of lambs could be started when the lambs are 3 or 4 months old or after weaned (Laws, 2014). The important thing of fattening lambs is the physiological condition of the digestive tracts. The rumen of the lambs is physiologically still developing when the lamb starts to eat the solid and high fibre containing feed (Heinrichs, 2005). Rumen has an important function in digestion process since $60-80 \%$ of feed is prepared in the rumen before being digested and absorbed in the small intestine (Yahaghi et al., 2013). Therefore, it becomes very important to understand the growth of digestive tract of lambs as well as its function to digest feed and determine the feed should be given.

The digestive tracts function to digest feed is usually determined by using digestion trial method by recording feed intake and faeces excretion. Another method that can be used to observe the function and ability of digestive tracts is by observation of eating behaviour. The eating and ruminating time related to the ability of the physical and biological digestive organs. The physical digestion occurs in the mouth by the teeth to break the feed into smaller particle size becomes faster when the teeth well developed. Therefore, the time required to consume the feed in large quantities become less. As a consequence, the feed will be easy to escape from the rumen, the amount of feed re-chewed and time of rumination also becomes less. Eckert et al. (2015) showed that the feed intake of calves in 8 weeks old was higher than those of calves in 6 weeks old. They has similarity of ruminating time but the efficiency of ruminating was higher in calves ages 8 weeks than those of calves age 6 weeks. Moreover, the growth of rumen affects the biological digestive process. Beside the age, the form and nutrient content of feed especially fibre affect on the time of eating and ruminating and also digestibilty (Lee et al., 2010; Suzuki et al., 2014). Shou-kun et al. (2016) reported that the weaning lambs were fed totally grass had different digestibilty with those fed high concentrate.

From those explanation, eating and ruminating time and digestibility of feed perhaps can shown the development of digestive tract. It is necessary to evaluate the responses of eating behaviour, feed digestibility of lambs and sheep fed different feed.

\section{MATERIALS AND METHODS}

\section{Animals and experimental design}

This study used eleven male lambs aged 3-4 months old, weighed $14.78 \pm 1.99 \mathrm{~kg}$ (CV $3.98 \%$ ), and eleven ram aged 10-12 months old, weighed $22.18 \pm 1.81 \mathrm{~kg}$ (CV 3.29\%). They were raised in individual pen equipped with feeding and drinking bunk.

This study used a complete randomized nested design of $2 \times 2$. There were two ages compared (lambs vs ram) and every age was nested diet as a treatment, i.e. $100 \%$ Napier grass chopped with size $2-3 \mathrm{~cm}$ (G100) vs. mixed pellet feed of $50 \%$ grass: $50 \%$ concentrate (G50C50). The diet was given as much as $3.5 \%$ of body weight. In dry matter (DM) base. The diet ingredients and composition are shown in Table 1. The parameters observed were the digestibility of dry matter (DM), organic matter (OM), crude fibre $(\mathrm{CF})$ and crude protein $(\mathrm{CP})$ of feed, eating and ruminating time.

This study was conducted on 3 stages, namely preparation for 1 week, adaptation for 1 month, and treatment for 1 month. In the preparation stage, the animals were given vitamin (Biosalamin ${ }^{\circledR}$ ) at a dose of $1 \mathrm{ml}$ per $10 \mathrm{~kg}$ of body weight to recover their body condition from stress after transportation and injected with Ivomec ${ }^{\circledR}$ at a doses of $1 \mathrm{~mL}$ per $25 \mathrm{~kg}$ of body weight for the preventing endoparasites and ectoparasites. In the stage of adaptation, the animals were offered the experimental diets to familiarize with them. The adaptation period was finished after the animal being able to consume the diet at least $3.0 \%$ of body weight. The treatment phase was begun with randomization of animals to the treatment, followed by data collection for 4 weeks.

\section{Observation Eating and Ruminating Behaviour}

Eating and ruminating behaviour of the experimental animals was done by manually observing animals activity every 5 minutes for $2 \mathrm{x}$ 24 hours. The observation was recorded on the observation form. Eating time was calculated when the head of the animals is in the feed bunk and consume the feed. The ruminating time was calculated when the animals were chewing 
outside the feed bunk without showing eating activity.

\section{Determination of Feed Digestibility and Distribution of Faecal Particle size}

The digestibility was determined by total collection method, namely observing the feed intake and faecal excretion in consecutive 7 days. The feed and faeces were analysed by proximate analysis according to the AOAC (2005) to measure the value of feed digestibility.

\section{Data analysis}

The data of eating and ruminating time and feed digestibility were analyzed using analysis of variance (ANOVA) with 95\% level of significance.

\section{RESULTS AND DISCUSSION}

\section{Feed Intake and Digestibility}

The feed intake and digestibility of DM, $\mathrm{OM}, \mathrm{CP}$ and $\mathrm{CF}$ of lambs and ram with different feed are shown in Table 2. The intake of dry matter (DM), organic matter (OM), crude protein (CP) and crude fibre (CF) of male lambs and ram were affected by diet $(\mathrm{P}<0.05)$; in which diet G50C50 led to higher DM, OM, CP and CF intakes than that diet G100. The greater intake of $\mathrm{OM}$ and CP of G50C50 was primarily due to the higher DM intake compared with that of G100, in which caused by the $\mathrm{CF}$ content of G100 was higher than that of G50C50 (Table 1). Higher CF content in the diet results in lower digestibility and DM intake (McDonald et al., 2012; Schulze et al., 2014).

Dry matter intake was affected by the age of animal $(\mathrm{P}<0.05)$, both in G100 and G50C50. This result was accompanied by $\mathrm{OM}, \mathrm{CP}$ and $\mathrm{CF}$ intake $(\mathrm{P}<0,05)$. Dry matter intake of ram was higher than that of lambs. This was attributed to the fact that ram had higher body weight than the lambs. Animal with higher body weight have greater gut capacity and need more nutrients for maintenance (McDonald et al., 2012; Luthfi et al., 2014).

There was no significant difference $(\mathrm{P}>0.05)$ between lambs and ram in the digestibility of DM, $\mathrm{OM}, \mathrm{CF}$ and $\mathrm{CP}$, both being fed G100 and G50C50. This indicated that the digestive tracts of the lambs had achieved the phase of development as those of mature sheep. In the newly born ruminant, the rumen has not functioned, and the volume was only about $30 \%$ of the total gut capacity. The rumen then develops and starts to
Table 1. Feed Composition and Nutrient Content of Feed for Lambs and Sheep

\begin{tabular}{lcc}
\hline \multirow{2}{*}{ Feedstuff } & \multicolumn{2}{c}{ Feed Composition } \\
& G100 & G50C50 \\
\hline & $-----(\%)$ & ---- \\
Napier grass & 100 & 50 \\
Concentrate & - & 50 \\
$\quad$ - Cassava meal & - & 8 \\
$\quad$ - Rice bran & - & 9 \\
- Wheat bran & - & 18 \\
- Soy bean meal & - & 8 \\
$\quad$ - Molasses & - & 5 \\
$\quad$ - Mineral mix & - & 2 \\
Nutrient content & $-----100 \%$ DM ---- \\
Ash & 23.03 & 16.50 \\
Ether extract & 1.18 & 19.88 \\
Crude fibre & 34.43 & 26.02 \\
Crude protein & 8.77 & 12.56 \\
Nitrogen free extract & 32.59 & 25.04 \\
Total digestible nutrients & 41.85 & 50.34 \\
\hline
\end{tabular}

function when the animal consumes fibrous feed. In the mature animal, the rumen takes about $85 \%$ of the total gut capacity (Baldwin, 2000).

The results of this study were similar to the report of Estermann et al. (2002) that cattle aged 4, 7 and 10 months had the same ability in digesting feed. Similar result was also reported by Luthfi et al. (2014) that goats aged 6 and 12 months had similar ability to digest feed.

Dry matter digestibility was higher both in lambs and ram in diet G50C50 than that of diet G100 $(\mathrm{P}<0.05)$. This was due to the fact $\mathrm{CF}$ content of diet G50C50 was lower than that of diet G100. This was consistent with the findings of Silva et al. (2015) that sheep fed $60 \%$ Stylosanthes grass and $40 \%$ concentrate, had $70 \%$ DM digestibility, while sheep fed $100 \%$ Stylosanthes grass had the 52\% DM digestibility. One of the nutritional factors which influence feed digestibility is dietary $\mathrm{CF}$ content. The higher $\mathrm{CF}$ content in the diet results in a lower digestibility of the diet. The high dietary CF content protect the other nutrients from digestion by digestive enzyme. 
Table 2. Nutrient Intake and Nutrient Digestibility of Lambs and Ram Sheep Fed G100 and G50C50

\begin{tabular}{|c|c|c|c|c|c|c|c|c|c|c|}
\hline \multirow[t]{2}{*}{ Paramater } & \multicolumn{4}{|c|}{ Lambs } & \multicolumn{4}{|c|}{ Ram } & \multicolumn{2}{|c|}{$\begin{array}{l}\text { Sig between } \\
\text { Age }\end{array}$} \\
\hline & G100 & G50C50 & Ave & Sig & G100 & G50C50 & Ave & Sig & G100 & G50C50 \\
\hline Body Weight (kg) & 14.40 & 15.10 & 14.75 & & 21.18 & 23.02 & 22.10 & & & \\
\hline DM Intake (g/d) & 452.98 & 530.84 & 491.91 & $\mathrm{~s}$ & 676.39 & 800.67 & 738.53 & $\mathrm{~s}$ & $\mathrm{~s}$ & $\mathrm{~s}$ \\
\hline DM Intake (\% BB) & 3.15 & 3.50 & 3.33 & $\mathrm{~s}$ & 3.19 & 3.48 & 3.33 & $\mathrm{~s}$ & ns & ns \\
\hline OM Intake (g/d) & 348.66 & 441.56 & 395.11 & $\mathrm{~s}$ & 486.32 & 668.56 & 586.44 & $\mathrm{~s}$ & $\mathrm{~s}$ & $\mathrm{~s}$ \\
\hline CF Intake (g/d) & 155.96 & 138.10 & 294.06 & $\mathrm{~s}$ & 232.88 & 208.34 & 220.61 & $\mathrm{~s}$ & $\mathrm{~s}$ & $\mathrm{~s}$ \\
\hline CP Intake (g/d) & 39.77 & 66.67 & 53.22 & $\mathrm{~s}$ & 59.39 & 100.56 & 79.97 & $\mathrm{~s}$ & $\mathrm{~s}$ & $\mathrm{~s}$ \\
\hline DM Digestibility (\%) & 46.80 & 50.23 & 48.51 & $\mathrm{~s}$ & 48.25 & 50.74 & 49.49 & $\mathrm{~s}$ & $\mathrm{~ns}$ & $\mathrm{~ns}$ \\
\hline OM Digestibility (\%) & 60.49 & 71.50 & 65.99 & s & 62.71 & 71.13 & 66.92 & $\mathrm{~s}$ & ns & ns \\
\hline CF Digestibilty (\%) & 41.61 & 26.78 & 34.19 & $\mathrm{~s}$ & 39.37 & 28.31 & 33.84 & $\mathrm{~s}$ & $\mathrm{~ns}$ & $\mathrm{~ns}$ \\
\hline CP Digestibilty (\%) & 53.73 & 70.15 & 61.94 & $\mathrm{~s}$ & 63.07 & 67.12 & 65.09 & $\mathrm{~s}$ & ns & ns \\
\hline
\end{tabular}

The different digestibility of DM in diet G5050C and diet G100 was parallel with different digestibility of $\mathrm{OM}, \mathrm{CF}$, and $\mathrm{CP}$. Aksu et al. (2006) stated that the different digestibility of DM will be followed by the digestibility of nutrient content of feed. The research of Liu et al. (2005) showed that sheep allowed to $15 \%$ concentrate had $61.20 \%$ OM digestibility, while sheep allowed to $35 \%$ concentrate had $70.98 \%$ OM digestibility. The CP digestibility on this study was agree with Rao and Kumar (2015) who found that the higher dry matter digestibility and percentage protein content in the feed, the higher the protein digestibility.

The CF digestibility of diet G50C50 was lower $(\mathrm{P}<0.05)$ than that of $\mathrm{G} 100(\mathrm{P}<0.05$, see Table 2). This can be attributed to the dietary $\mathrm{CF}$ content of G100 being higher than that of G50C50. In the ruminant, CF digestibility is influenced by the population of cellulotic microbes in the rumen. It seemed that the population of ruminal cellulolitic microbes in the animals fed G50C50 developed less than in those fed G100. The diet G50C50 contained more nitrogen free extract (NFE) which was notably much more digestible than $\mathrm{CF}$ and causing amylolitic microbes to thrive more than the cellulolitic ones. This was in accordance with Van Soest (1994) that the development of microbes in digesting feed is very dependent on the ingredients of feed intake. The results of this study were similar to Klinger et al. (2007), who reported that in cattle fed with higher content of fibre causes higher crude fibre digestibility value compared with feed containing lower fibre.

\section{Eating and Ruminating Behaviour}

Eating and ruminating behaviour (eating and ruminating time) and the value of the efficiency of eating and ruminating are shown in Table 3. Eating and ruminating times were not significantly different $(\mathrm{P}>0.05)$ between lambs and ram. The non-significant eating and ruminating time of the lambs and ram indicated that the animals had similar allocation time for eating activities.

Eating and ruminating efficiency of lambs was lower $(\mathrm{P}<0.05)$ than that of ram, in the both diets. This data indicated that given the same time, the ram ate more feed that the lambs. This was due to the larger body size and oral cavity of the ram that was bigger than of the lambs, causing higher capability to accommodate a large amounts of feed per unit of time. An experiment by Ali et al. (1990) found that the ability of buffalo to take or grab the feed increases following the age.

Eating efficiency of lambs and ram fed diet G50C50 was higher than those fed G100. It was 
Table 3. Eating and ruminating behaviour of male lambs and ram fed with G100 and G50C50

\begin{tabular}{|c|c|c|c|c|c|c|c|c|c|c|}
\hline \multirow[t]{2}{*}{ Paramater } & \multicolumn{4}{|c|}{ Lambs } & \multicolumn{4}{|c|}{ Ram } & \multicolumn{2}{|c|}{$\begin{array}{l}\text { Sig Between } \\
\text { Age }\end{array}$} \\
\hline & G100 & G50C50 & Ave & Sig & G100 & G50C50 & Ave & Sig & G100 & G50C50 \\
\hline $\begin{array}{l}\text { Eating Time } \\
\text { (minute/d) }\end{array}$ & 319.00 & 45.83 & 182.41 & $\mathrm{~s}$ & 357.50 & 47.92 & 202.71 & $\mathrm{~s}$ & ns & ns \\
\hline $\begin{array}{l}\text { Ruminating Time } \\
\text { (minute/d) }\end{array}$ & 389.50 & 337.92 & 363.71 & $\mathrm{~s}$ & 456.50 & 272.08 & 364.29 & $\mathrm{~s}$ & ns & ns \\
\hline $\begin{array}{l}\text { Eating Efficiency } \\
\text { (g/minute) }\end{array}$ & 1.24 & 12.50 & 6.87 & $\mathrm{~s}$ & 1.90 & 17.96 & 9.93 & $\mathrm{~s}$ & $\mathrm{~s}$ & $\mathrm{~s}$ \\
\hline $\begin{array}{l}\text { Ruminating Efficiency } \\
\text { (g/minute) }\end{array}$ & 1.14 & 1.56 & 1.35 & $\mathrm{~s}$ & 1.55 & 2.78 & 2.1 & $\mathrm{~s}$ & $\mathrm{~ns}$ & $\mathrm{~s}$ \\
\hline
\end{tabular}

Ave $=$ Average; $\mathrm{s}=$ significant $(\mathrm{P}<0.05) ; \mathrm{ns}=$ non significant $(\mathrm{P}>0.05)$

because of smaller particle size and higher digestibility of diet G50C50. Smaller size and higher digestibility of feed made animals able to take more feed per unit of time than the larger size. That was in line with Verdu et al. (2016) who found that pelleted feed could improve the efficiency of eating time, at which cattle fed pelleted feed were able to intake the feed of 193 $\mathrm{g} / \mathrm{min}$ while the crumble-shaped feed only 174 $\mathrm{g} / \mathrm{min}$.

Lambs and ram fed diet G50C50 required a shorter time $(\mathrm{P}<0.05)$ for eating and ruminating compared with those fed G100. The results were due to the different form and fibre content of diet. Diet G50C50 was easier to chew because it was in the form of pellet and contained lower crude fibre, while diet G100 was in the form of chopped grass with size of 2-3 cm and contained higher crude fibre. Chewing during eating aimed to minimize feed particles to be easy to swallow. A study by Lee et al. (2010) found that the physical shape and characteristics of feed affected eating time. The results of this study was in agreement with Polat et al. (2013), in which lambs fed chopped corn silage containing $25.2 \%$ crude fibre took 219.8 minutes to eat, while lambs fed bit pulp with $17.5 \%$ crude fibre content only required 189.7 minutes.

Ruminating efficiency of the lamb was lower than that of the ram. It was because of oral cavity and teeth in mature mature sheep had developed completely, while in lambs were still developing. That was in accordance with Bae et al. (1983) that the efficiency of eating and ruminating of mature animals was higher than that of the young ones.

Although the feed intake of G50C50 was higher than $\mathrm{G} 100$, the ruminating efficiency was not significantly different $(\mathrm{P}>0.05)$. It was caused by feed particles size in which on G50C50 resulted from chewing activity was smaller than of G100. Smaller feed particles cause the feed to pass easily in the rumen so that the amount feed that must be ruminated was reduced. Fischer et al. (1993) observed that feed with small particles easily escapes from the rumen, and feed with small particles is not able to stimulate the rumen to rumination.

\section{CONCLUSION}

Based on these results, it can be concluded that the digestive tracts of lambs aged 3-4 moths has developed as those of mature. Feeding of diet containing $50 \%$ grass and $50 \%$ concentrate results in better feed digestibility, feed intake and eating efficiency than diet containing $100 \%$ grass. Therefore, it can be recommended that lambs can be fattened at early age with diet that partly consisted of grass.

\section{ACKNOWLEDGMENTS}

The authors thanks to Ministry of Research and Higher Education of the Republic of Indonesia for scholarship of Master Program of Education Leading to Doctoral Degree for Excellent Graduates (PMDSU 2015). 


\section{REFERENCES}

AOAC. 2005. Official Methods of Analysis: 18th Edition. Association of Official Analytical, Chemists International, Maryland, USA.

Aksu, T., E. Baytok, M. A. Karsl and H. Muruz. 2006. Effects of formic acid, molasses and inoculant additives on corn silage composition, organic matter digestibility and microbial protein synthesis in sheep. Small Rum. Res. 61:29-33.

Ali, A., S.H. Raza and A. Ghaffar. 1990. Eating and rumination in relation.to age of lactating buffalo. Appl. Anim. Behav. Sci. 28:273-279.

Bae, D.B., J.G. Welch, and B.E. Gilman. 1983. Mastication and rumination in relation to body size of cattle. J. Dairy Sci. 66:21372141.

Baldwin, R.L. 2000. Sheep gastrointestinal development in response to different dietary treatments. Small Rum Res 35:39-47

Boulghami A and A. Araba. 2016. Effect of feeding management from grass to concentrate feed on growth, carcass characteristics, meat quality and fatty acid profile of Timahdite lamb breed. Small Rum Res 144:158-163.

Estermann, B. L., F. Sutter, P.O. Schlegel, D. Erdin, H.R. Wettstein and M. Kreuzer. 2002. Effect of calf age and dam breed on intake, energy expenditure, and excretion of nitrogen, phosporus, and methane of beef cows with calves. J. Anim Sci. 80:11241134.

Fischer, J. M., J. G. Buchanan-Smith, C. Campbell, D. G. Grieve, and O. B. Allen. 1994. Effects of forage particle size and long hay for cows fed total mix rations based on alfafa and corn. J. Dairy. Sci. 77: 217-229.

Heinrichs, J. 2005. Rumen development in the dairy calf. Adv Dairy Technol. 17: 179-184.

Klinger, S. A., H. C. Block, and J. J. McKinnon. 2007. Nutrient digestibility, fecal output and eating behavior for different cattle background feeding strategies. Can. J. Anim. Sci. 87:393-399.

Laws, D and L, Genever. 2014. Growing and finishing lambs for Better Returns. EBLEX Division, Warwickshire.

Lee, S., Y. Kim, Y. Oh and W. Kwak. 2010. Effects of feeding methods of total mixed ration on behavior patterns of growing
Hanwoo Steers. Asian-Aust. J. Anim. Sci. 23(11): 1469-1475.

Liu, X., Z. Wang and F. Lee. 2005. Influence of concentrate level on dry matter intake, $\mathrm{N}$ balance, nutrien digestibility, ruminal outflow rate, and nutrien degradability in sheep. Small Rum. Res. 58:55-62.

Luthfi, N., C.M.S. Lestari and A. Purnomoadi. 2014. Ruminal fermentation and blood glucose at low and high level intake growing and mature Kacang goat. J. Indonesian Trop. Anim. Agric. 39(3):152158.

McDonald, P., R.A.Edwards, J.F.D. Greenhalgh, C.A. Morgan, L.A. Sinclair and R.G. Wilkinson. 2012. Animal Nutrition, Seventh Edition. Pearson, Harlow (England).

Polat E. S., B. Coskun, E. Gurbuz and T. Balevi. 2013. The effects of roughage type on the daily patterns of feed intake and eating behaviour in young sheep. Revue Méd. Vét. 164(11): 503-510.

Purnomoadi, A., V. Restitrisnani, N. Luthfi, A. Prima and E. Rianto. 2016. Methane mitigation by shortening duration of rearing the lamb by increasing daily gain giving higher dietary protein content - case study of Indonesia. Asian-Australasian of Animal Production Satellite Workshop on Mitigation of Greenhouse Gases and Adaptation to Climate Change in Livestock Production Systems, Kyushu Sangyo University, Fukuoka, Japan 23 August 2016. P. 6.

Rao, S.B.N. and D. D.Kumar. 2015. Effect of substitution of soybean meal by detoxified karanjacake on diet digestibility, growth, carcass and meat traitsof sheep. Small Rum. Res. 126: 26-33.

Schulze, A.K.S., M. R. Weisbjerg, A.C. Storm and P. Nørgaard. 2014. Forage fiber effects on particle size reduction, ruminal stratification, and selective retention in heifers fed highly digestible grass/clover silages. J. Anim. Sci. 92:2511-2521.

Shou-kun, Jl., J. Cheng-gang, Li Rui, D. Qi-Yu, Tu Yan, Z. Nai-feng and S. Bing-wen. 2016. Growth performance and rumen microorganism differ between segregated weaning lambs and grazing lambs. J.I. Agri 15(4):872-878.

Silva, A.M.A., A.G.S. Sobrinho, I.A.C.M. Trindade, K.T. Resende and O.A. Bakke. 2004. Food intake and digestive efficiency 
in temperate wool and tropic semi-arid hair lambs fed different concentrate: forage ratio diets. Small Rum. Res. 55:107-115.

Silva, T.C., O.G. Pereira, M.C.N. Agarussi, V.P. da Silva, L.D. da Silva, L.L. Cardoso, K.G. Ribeiro and S.C.V. Filho. 2015. Stylosanthes cv. Campo Grande silage with or without concentrate in sheep diets: Nutritional value and ruminal fermentation. Small Rumin. Res. 126:34-39.

Suzuki, T., Y. Kamiya, M. Tanaka, I. Hattori, T. Sakaigaichi, T. Terauchi, I. Nonaka and F. Terada. 2014. Effect of fiber content of roughage on energy cost of eatingand rumination in Holstein cows. Anim Feed. Sci and Tech. 196:42-49.
Van Soest P.J. 1994. Nutrional Ecology of The Ruminant. Cornell University Press, Ithaca.

Verdú, M., A. Bach and M. Devant. 2016. Effect of concentrate presentation form on concentrate wastage, eating pattern, and concentrate preference in Holstein bulls fed a finishing high-concentrate diet. Anim. Feed Sci. and Tech. 219:257-267.

Yahaghi, M, J.B. Liang, J. Balcells, R. Valizadeh, A.R. Seradj, R. Alimon and Y.W. Ho. 2013. Effect of substituting barley with sorghum on starch digestion, rumen microbial yield and growth in Iranian Baluchi lambs fed high concentrate diets. Anim. Feed Sci. and Tech. 183:96-105. 